\title{
Cultivation of Agaricus bisporus X25 on Reed Plant (Phragmites australis) Straw Decomposed by Using Actinomycetes
}

\section{Agaricus bisporus X25'in Actinomycetes Kullanarak Saz Bitkisi (Phragmites australis) Üzerinde Yetiştirilmesi}

\author{
Research Article
}

\author{
Mustafa Nadhim Owaid 1,2*, Mowafaq Mezban Muslat ${ }^{3}$, Idham Ali Abed ${ }^{4}$ \\ 'Al-Athar School, Heet Education, General Directorate for Education of Anbar, Ministry of Education, Hit, Anbar, Iraq. \\ 'Department of Biology, College of Science, University of Anbar, Ramadi, Anbar, Iraq. \\ ${ }^{3}$ Department of Horticulture, College of Agriculture, University of Anbar, Ramadi, Anbar, Iraq. \\ ${ }^{4}$ Department of Soil Science and Water Resources, College of Agriculture, University of Anbar, Ramadi, Anbar, Iraq.
}

\section{ABSTRACT}

\begin{abstract}
The reed plant is available as economic alternative instead of wheat straw in state unavailable or the high prices to use it in the preparing compost for cultivation of Agaricus bisporus X25. In significant $(P<0.05)$, use of Streptomyces inoculum led to increase the total yield of $A$. bisporus X25 during 21 days to $430 \mathrm{~g} / \mathrm{box}(\mathrm{g} / 5 \mathrm{~kg}$ compost based on wet matter) compared without treatment ( $376.94 \mathrm{~g} / \mathrm{box}$ ). The treated reed straw showed higher yield $496.33 \mathrm{~g} /$ box. Using bacterial inoculum given biological efficiency $26.3 \%$ compared without treatment $23.8 \%$. The best biological efficiency was $29.3 \%$ with treated reed straw compost using bacterium Streptomyces, while, the lower value was $20.8 \%$ for the mixture compost in same previous case. Quality and size of fruiting bodies were varied from compost to another one depended on diameter of cap (pileus), length of stipe. The bigger diameter had been recorded $55.83 \mathrm{~mm}$ for fruits of reed straw compost while the lower diameter was $42.33 \mathrm{~mm}$ on fruits of control compost.
\end{abstract}

\section{Key Words}

Bio-recycling, compost, food, white button mushroom.

\section{öz}

az bitkisi, Agaricus bisporus X25'in yetiştirilmesi için buğday samanının, hazırlama kompostunda
kullanılmak üzere bulunmadığı veya yüksek maliyetli olduğu durumlarda ekonomik bir alternatif olarak
kullanılır. Belirgin olarak ( $\mathrm{P}<0.05$ ) Streptomyces inoclum'unun (aşı) kullanılması iyileştirme yapılmayan
durumla ( $376.94 \mathrm{~g} /$ kutu) karşılaştırıldığında 21 gün süresince $430 \mathrm{~g} /$ kutu (ıslak maddeye bağlı olarak g/5 kg
kompost) miktarına kadar toplam A. bisporus X25 veriminde artışa neden olmuştur. Iyileştirilmiş saz samanı
$496.33 \mathrm{~g} /$ kutu olmak üzere yüksek verim göstermiştir. Bakteriyel inoklum kullanılması iyileştirme yapılmayan
durumla karşılaştırıldığında (\%23.8) biyolojik etkinlik sağlamıştır (\%26.3). Streptomyces bakterisi kullanılarak
iyileştirilmiş saz samanı ile en iyi biyolojik etkinlik değeri \%29.3 olup, önceki durumdaki kompost karışımı için
değer \%20.8'dir. Sporokarpların kalitesi ve büyüklüğü komposttan diğer başlığın çapına ve sapın uzunluğuna
bağlı olarak değişmektedir. Kontrol kompostu meyveleri üzerindeki saz samanı meyveleri için kaydedilmiş en
büyük çap $55.83 \mathrm{~mm}$ iken en düşük çap $42.33 \mathrm{~mm}$ 'dir.

\section{Anahtar Kelimeler}

Bio-geri dönüşüm, kompost, gıda, beyaz düğme mantar.

Article History: Received: Jul 7, 2016; Revised: Sep 15, 2016; Accepted: Sep 20, 2016; Available Online: Apr 1, 2017.

DOI: 10.15671/HJBC.2017.153

Correspondence to: M.N. Owaid, İnönü University, Department of Biology, College of Science, University of Anbar, Ramadi, Anbar, Iraq. 


\section{INTRODUCTION}

T he edible mushroom Agaricus bisporus, one of fleshy fungi, belongs to Basidiomycota. It has high nutritive value due to its high protein content [1]. A. bisporus is a mushroom that grows upon decomposed organic matters. Generally, edible mushrooms don't have ability for using energy of sun to produce the carbohydrates because lacking chlorophylls [2]. The potential of bio-conversion of lignocellulosic wastes into value-added products was tested in recent studies [3]. A. bisporus can be grown on wheat straw [4], sawdust mixed with wheat straw [5], waste tea leaves [6,7], waste paper [8,9], common reed [10-12] and sunflower head composts [13].

Medicinally, Hippocrates first referred to medicinal mushrooms in treatment in 400 B.C. while the first mention of cultivation of mushroom was in 1652 when appeared in the field naturally [14]. Extracts of $A$. bisporus has antimicrobial [15] and anticancer activities [16], also it used to treat atherosclerosis and diabetes; and to treat obesity because of its low calories [17]. A bisporus has some useful mineral elements such as $\mathrm{Na}, \mathrm{K}, \mathrm{Pb}, \mathrm{Co}, \mathrm{Fe}, \mathrm{Cr}, \mathrm{Cu}, \mathrm{Ni}, \mathrm{Zn}, \mathrm{Mn}$ and $\mathrm{Cd}$. These microelements encourage the citizens for consuming healthy food [18]. Also, it is contains elemental $\mathrm{P}, \mathrm{S}, \mathrm{Ca}$ and $\mathrm{Li}$, without starch and rich of essential vitamins $A, B, C$, and D [19].

The genus Streptomyces is one of most genera of Actinomycetes in economical state; it belongs to the family Streptomycetaceae and order Actinomycetals [20]. It is filament bacteria, aerobic and gram positive charge [21]. The bacterium Streptomyces has wide distribution in the various environments (soil, water and air). But the soil is a major source for this bacterium [22]. Also, it finds in other ecological media such as organic fertilizers, manure, plant matters and upon surface of plant [23]. The warm places are more adequate to grow huge numbers of this bacterium; also the organic matters are useful and necessary factor to grow this microorganism [24]. Actinomycetes diminished rapidly with the latter disappearing after 6 weeks [25], thus this bacterium was used to decompose composts in this work to raise total yield of Agaricus bisporus X25 on those local composts.

\section{MATERIALS and METHODS}

\section{Mushroom Strain}

The mushroom spawn of white button mushroom Agaricus bisporus X25 was obtained from Le Lion Company, France by the Hameediyah Mushroom Farm (HMF), Ramadi, Kilo 18.

\section{Bactria Strain}

Bactrium Streptomyces obtained from Department of Biology, College of Science, University of Anbar which isolated from Ramadi soils, Iraq. This bacterium was used as inoculum at concentration $10^{6} \mathrm{cfu}$ (cells)/g of solid substrate/compost during composting process.

\section{Preparing Inoculum of Streptomyces}

This bacterium Streptomyces maintenances using Gauze Agar medium which composing from $20 \mathrm{~g}$ soluble starch, $1 \mathrm{~g} \mathrm{KNO}_{3}, 0.5 \mathrm{~g} \mathrm{NaCl}$, $0.5 \mathrm{~g} \mathrm{MgSO}_{4} .7 \mathrm{H}_{2} \mathrm{O}, 0.5 \mathrm{~g} \mathrm{~K}_{2} \mathrm{HPO}_{4}$ and $0.001 \mathrm{~g}$ $\mathrm{FeSO}_{4} \cdot 5 \mathrm{H}_{2} \mathrm{O}$ which dissolved in $1 \mathrm{~L}$ of tap water. The $\mathrm{pH}$ of medium was adjusted to 7.2-7.4 then agar added and autoclaved. Then nutrient broth used to prepare the Streptomyces inoculum at concentration $10^{6} \mathrm{cfu} / \mathrm{g}$ of solid compost.

\section{Proportions of Mushroom Composts}

Below, details of each formula and its $C: N$ ratio which obtained from local gardens in Hit, Iraq. The main lignocellulosic matters are formed from

Table 1. Properties and compositions of composts of harvested Agaricus bisporus X25 in this study.

\begin{tabular}{cccc}
\hline Materials $(\mathbf{k g})$ & Wheat straw compost & Reed straw compost & Mixture compost 1:1 \\
\hline Wheat straw & 50 & - & 25 \\
\hline Reed straw & - & 50 & 25 \\
\hline Chicken manure & 41.2 & 41.2 & 41.2 \\
\hline Urea & 2.47 & 2.47 & 2.47 \\
\hline Gypsum & 6.33 & 6.33 & 6.33 \\
\hline C:N Ratio & $10: 1$ & $22: 1$ & $20: 1$ \\
\hline
\end{tabular}




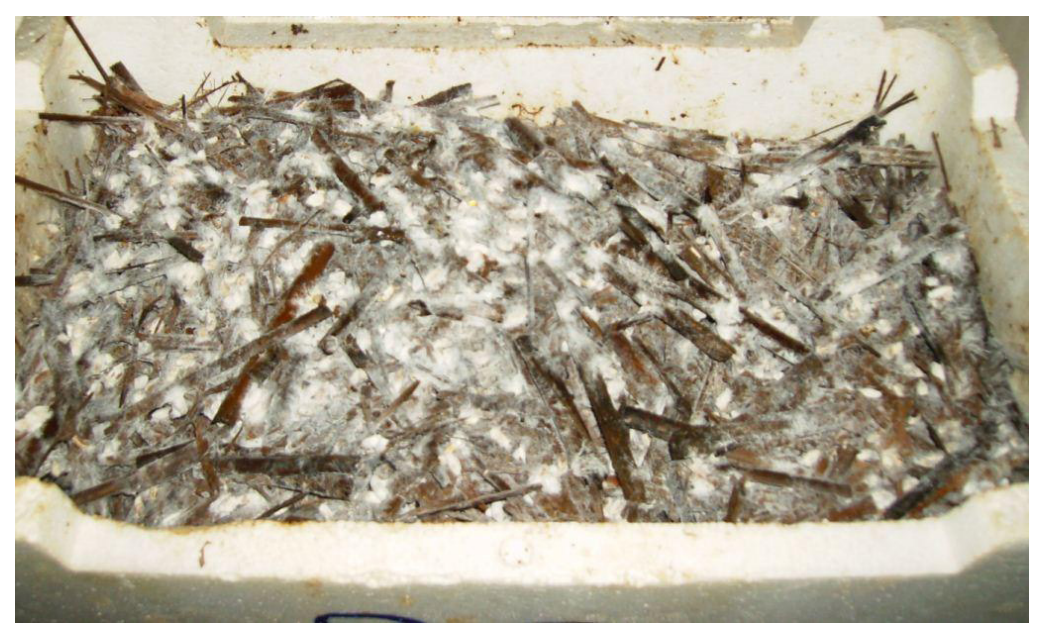

Figure 1. Mycelial growth completion of A. bisporus X25 on reed straw compost in the box.

wheat (Triticum sativum) straw, reed (Phragmites australis) straw and their mixture 1:1 [26].

\section{Composting, Pasteurization and Cultivation}

Solid state fermentation was achieved outdoor and indoor during phase 1 and phase 2 respectively as mentioned by Alheeti [26]. After pasteurization of compost and cooling, mushroom spawn was applied within bed at percent $2 \%$ based on dry weight using ruffling method until mycelial growth completion (Figure 1). Pasteurizing casing layer was applied which consisted from peat moss and soil. Other processes were used as mentioned by Alheeti [26]. Casing layer was used in depth 2.5 $\mathrm{cm}$ as mentioned by Royse [27].

\section{Determinations}

Total yield for 21 days, biological efficiency, number of fruiting bodies, diameter of cap, length of stipe and the ratio of diameter of cap to length of stipe were determined in three composts with or without decomposition using bacterium Streptomyces.

\section{Statistical Analysis}

Statistical significance was determined by using CRD (two ways) analysis of variance (ANOVA) by implementing GenStat Discovery Edition computer program version 7 DE3 (VSN International Ltd., UK). Significant differences at $P<0.05$ were considered. All the experiments were done in six replicates.

\section{RESULTS and DISCUSSION}

In significant $(P<0.05)$, the treatment using bacterium Streptomyces inoculum led to increase the total yield of fresh Agaricus bisporus X25 during 21 days to $430 \mathrm{~g} / \mathrm{box}$ ( $\mathrm{g} / \mathrm{box}$ which equal $5 \mathrm{~kg}$ compost based on wet matter) compared without treatment $(376.94 \mathrm{~g} / \mathrm{box})$. The treated reed straw compost showed higher yield 496.33

Table 2. Productivity and biological efficiency of Agaricus bisporus X25 after 21 days.

\begin{tabular}{|c|c|c|c|}
\hline \multirow[b]{2}{*}{ Treatments } & \multicolumn{2}{|c|}{ Yield (g/box) (box = $5 \mathrm{~kg}$ based on wet matters) } & \multirow[b]{2}{*}{ Mean of inoculum } \\
\hline & $\begin{array}{l}\text { Wheat straw } \\
\text { compost }\end{array}$ & $\begin{array}{l}\text { Mixture compost } \\
(1: 1)\end{array}$ & \\
\hline Without treatment & 344.83 & 400.67 & 376.94 \\
\hline $\begin{array}{c}\text { With bacterial } \\
\text { treatment }\end{array}$ & 397.50 & 396.17 & 430.00 \\
\hline LSD $(P<0.05)$ & & & 3.394 \\
\hline \multirow{2}{*}{ Without treatment } & \multicolumn{3}{|c|}{ Biological efficiency (\%) } \\
\hline & 22.7 & 25.1 & 23.8 \\
\hline $\begin{array}{l}\text { With bacterial } \\
\text { treatment }\end{array}$ & 28.8 & 20.8 & 26.3 \\
\hline $\operatorname{LSD}(P<0.05)$ & \multicolumn{2}{|c|}{10.82} & 6.24 \\
\hline
\end{tabular}




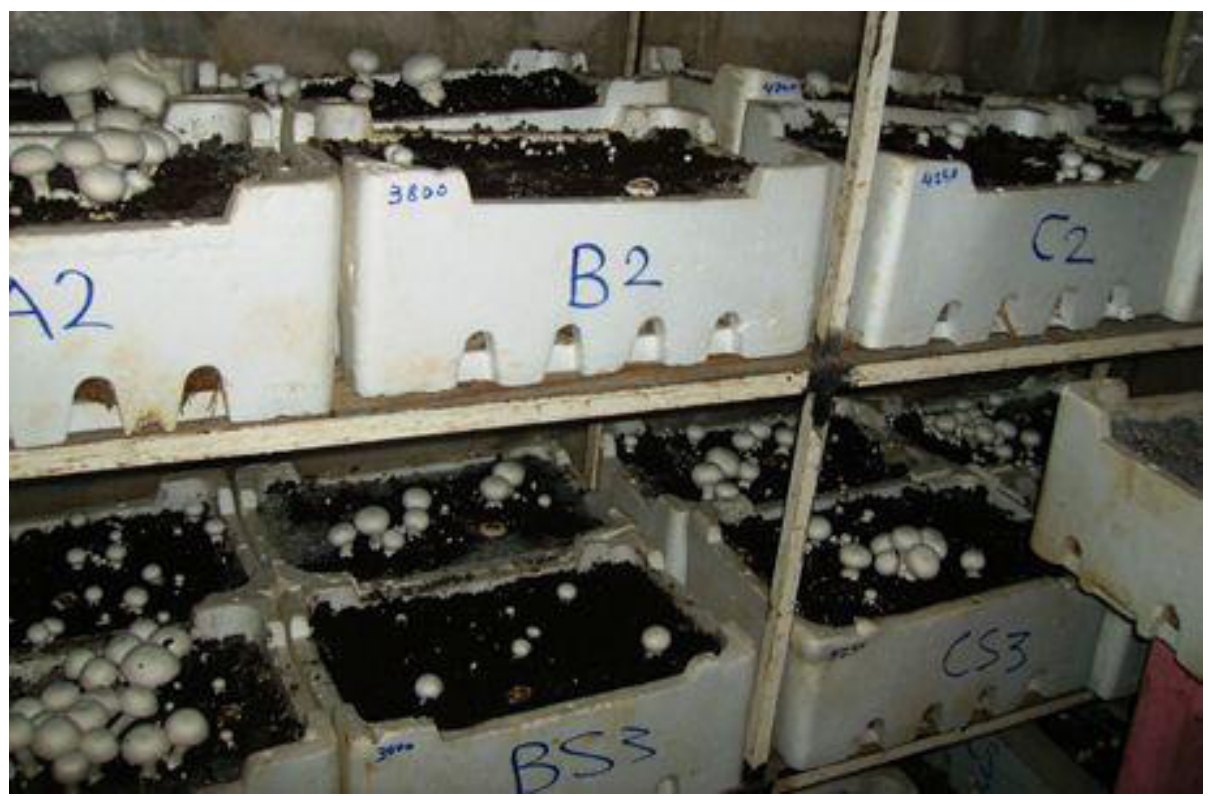

Figure 2. Fruiting bodies of Agaricus bisporus X25 in mushroom room. Legend: A2: wheat straw compost, B2: reed straw compost, C2: the mixture compost (1:1), AS3: wheat straw compost which decomposed using bacterial inoculum Streptomyces, BS3: reed straw compost which decomposed using Streptomyces. CS3: mixture compost which decomposed using Streptomyces.

$\mathrm{g} /$ box significantly $(P<0.05)$, followed 400.67 397.50 and $396.17 \mathrm{~g} / \mathrm{box}$ for the mixture compost with and without treatment and wheat straw compost with treatment respectively. While the lower productivity was $344.83 \mathrm{~g} / \mathrm{box}$ for wheat straw compost (control) in this trial (Table 2 and Figure 2).

Also, Table 2 showed the biological efficiency of $A$. bisporus $\mathrm{X} 25$ cultivated on three composts which treated with or without bacterial inoculum. The treated compost given biological efficiency $26.3 \%$ compared without treatment $23.8 \%$. The best biological efficiency was $29.3 \%$ with decomposed reed straw compost using bacteria Streptomyces, while, the lower biological efficiency was $20.8 \%$ for the mixture compost in same previous case.

Table 3 showed influence of treated compost using bacteria toward fruiting bodies number which reached to 12 fruits compared with approx. 11 fruits in case without treatment. The higher fruits number was observed on the treated wheat straw compost approx. 18 compared with the control (wheat straw compost) approx. 17 significantly $(P<0.05)$. The lower number was 7 fruits on reed straw compost. The treated mixture compost had 10 fruits.

Quality and size of fruiting bodies were varied from compost to another depended on diameter of cap (pileus), length of stipe (Table 4) and ratio of diameter of cap to length of stipe of fruiting bodies (Table 5). Diameter of cap recorded approx. $50 \mathrm{~mm}$ in this trail generally. Using bacteria in treatment gives diameter of cap $49.89 \mathrm{~mm}$ compared without treatment $(51.22 \mathrm{~mm}$ ). The bigger diameter had been noted on fruits of reed straw compost $55.83 \mathrm{~mm}$ while the smaller diameter was $42.33 \mathrm{~mm}$ on fruits of control compost. Also, using Streptomyces as a decomposer for composts leads to increase length of stipe to $31.28 \mathrm{~mm}$ compared without

Table 3. Number of Agaricus bisporus X25 fruiting bodies.

\begin{tabular}{|c|c|c|c|c|}
\hline Treatments & $\begin{array}{l}\text { Wheat straw } \\
\text { compost }\end{array}$ & $\begin{array}{l}\text { Reed straw } \\
\text { compost }\end{array}$ & $\begin{array}{c}\text { Mixture compost } \\
(1: 1)\end{array}$ & Mean of inoculum \\
\hline Without treatment & 16.50 & 7.17 & 8.83 & 10.83 \\
\hline $\begin{array}{l}\text { With bacterial } \\
\text { treatment }\end{array}$ & 18.33 & 7.67 & 10.00 & 12.00 \\
\hline $\operatorname{LSD}(P<0.05)$ & 0.932 & & & 0.538 \\
\hline
\end{tabular}


Table 4. Size of fruiting bodes of Agaricus bisporus X25.

\begin{tabular}{|c|c|c|c|}
\hline \multirow[b]{2}{*}{ Treatments } & \multicolumn{2}{|c|}{ Average of diameter of cap (mm) } & \multirow[b]{2}{*}{ Mean of inoculum } \\
\hline & $\begin{array}{l}\text { Wheat straw } \\
\text { compost }\end{array}$ & $\begin{array}{c}\text { Mixture compost } \\
(1: 1)\end{array}$ & \\
\hline Without treatment & 42.33 & 55.50 & 51.22 \\
\hline $\begin{array}{l}\text { With bacterial } \\
\text { treatment }\end{array}$ & 43.83 & 50.67 & 49.89 \\
\hline $\operatorname{LSD}(P<0.05)$ & \multicolumn{2}{|c|}{2.566} & 1.482 \\
\hline \multirow{2}{*}{ Without treatment } & \multicolumn{3}{|c|}{ Average of length of stipe (mm) } \\
\hline & 29.00 & 29.83 & 30.56 \\
\hline $\begin{array}{c}\text { With bacterial treat- } \\
\text { ment }\end{array}$ & 34.17 & 28.83 & 31.28 \\
\hline LSD $(P<0.05)$ & \multicolumn{2}{|c|}{1.708} & 0.986 \\
\hline
\end{tabular}

Table 5. Ratio of diameter of cap to length of stipe of fruiting bodies.

\begin{tabular}{|c|c|c|c|c|}
\hline Treatments & $\begin{array}{l}\text { Wheat straw } \\
\text { compost }\end{array}$ & $\begin{array}{c}\text { Reed straw } \\
\text { compost }\end{array}$ & $\begin{array}{c}\text { Mixture compost } \\
(1: 1)\end{array}$ & Mean of inoculum \\
\hline Without treatment & 1.467 & 1.712 & 1.858 & 1.679 \\
\hline $\begin{array}{l}\text { With bacterial } \\
\text { treatment }\end{array}$ & 1.283 & 1.800 & 1.775 & 1.619 \\
\hline $\operatorname{LSD}(P<0.05)$ & 0.1185 & & & 0.0684 \\
\hline
\end{tabular}

treatment $(30.56 \mathrm{~mm})$ the bigger length was 34.17 $\mathrm{mm}$ on fruits of the treated wheat straw compost compared with the control one $(29 \mathrm{~mm})$ as a lower value (Table 4).

If ratio of diameter of cap to length of stipe of fruiting bodies was more than 1 , that meaning useful in quality of mushroom. These results had been given significant $(P<0.05)$ value at level less than 0.05 (Table 5). The higher ratio was 1.85 with the mixture compost while the lower ratio was 1.28 with the treated wheat straw compost using Streptomyces.

Compost type or carbon source have significant $(P<0.05)$ influence on most properties of Agaricus bisporus X25 which seen in Figure 3. Reed straw compost recorded best yield ( 440.83 $\mathrm{g} /$ box) and biological efficiency (22.4\%) for wheat straw and the mixture composts, respectively.

- Wheat straw (WS) Reed straw (RS) $\approx$ Mixture 1:1 (WS:RS)

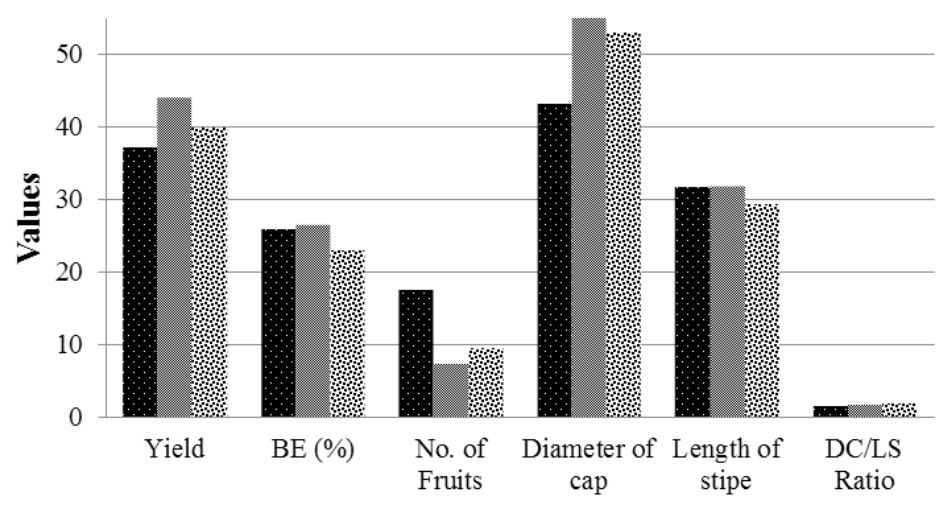

Figure 3. Type on some characteristics of mushroom A. bisporus. Legend: LSD $(p<0.05)$ for Yield $(\mathrm{g} / \mathrm{bog})=4.15, \mathrm{BE}(\%)$ $=7.65$, No. of Fruits $=0.659$, Diameter of $\operatorname{cap}(\mathrm{mm})=1.81$, Length of stipe $(\mathrm{mm})=1.20, \mathrm{DC} /$ LS Ratio=0.083. 
Table 6. Correlation among properties of mushroom.

\begin{tabular}{|c|c|c|c|c|c|c|}
\hline Correlation & yield & BE & Fruits No. & $\begin{array}{l}\text { Diameter } \\
\text { of cap }\end{array}$ & $\begin{array}{l}\text { Length of } \\
\text { stipe }\end{array}$ & $\begin{array}{c}\text { DC/LS } \\
\text { ratio }\end{array}$ \\
\hline $\mathrm{BE}$ & 0.483 & 1.000 & & & & \\
\hline Fruits No. & 0.084 & 0.267 & 1.000 & & & \\
\hline Diameter of cap & & $\begin{array}{r}0.153 \\
-0.155 \\
-0.865\end{array}$ & & 1.000 & & \\
\hline Length of stipe & -0.012 & 0.151 & 0.176 & -0.116 & 1.000 & \\
\hline DC/LS ratio & 0.127 & -0.202 & -0.770 & 0.848 & -0.618 & 1.000 \\
\hline
\end{tabular}

Legend: BE: biological efficiency, DC/LS ratio: diameter of cap to length of stipe ratio.

The bigger fruits number was approx. 17 fruiting bodies on wheat straw compost, significantly $(P$ <0.05). While bigger cap's diameter was $55.5 \mathrm{~mm}$ on reed straw compost and lower length of stipe was $29.33 \mathrm{~mm}$ on the mixture compost which given best DC/LS ratio (1.8).

In this study, biological efficiency is depend on total yield during 21 days as demonstrated by positive correlation between productivity (total yield) and biological efficiency (Table 6). According to compost weight, the mushroom yield on reed straw compost increased compared with the wheat straw and the mixture composts. The differences in yield may be return to difference those composts in capability of composts in ecological and nutritional requirements. Also, content of cellulose, hemicellulose and lignin was varied in these composts, which took place in numerous decomposition levels $[28,29]$. When mushroom yield increased, fruits sizes increased too as seen in Table 6 which demonstrated that in positive correlation between these characteristics.

From other side, type and size of compost constituents have important effect toward mushroom production, which demonstrates increasing number of fruiting bodies in the control compost because of its available nutrients in wheat straw and the mixture composts more than reed straw compost [12]. All that, led to increase surfaces of compost constituents which gave most decomposition and bigger fungal biomass. These results make to form greater fruits, sometimes appear in cluster form on casing layer [30]. Number of fruiting bodies decreased on reed straw compost in comparison with wheat straw and the mixture composts that due to difference proportions and constituents of each medium [26].

The reason of the high yield by using Streptomyces as an inoculum during composting phase may be return to ability this bacterium to give proteins, which lead to improve agromedia for $A$. bisporus cultivation. Extracts of bacteria also could inhibit growth of undesirable microorganisms such as green molds Trichoderma sp. and other pathogenic fungi [31] because of recording alkaline levels in compost when using Streptomyces [11]. Streptomyces adjust $\mathrm{pH}$ of media to alkaline by producing ammonia which helps to precipitate $\mathrm{CaCO}_{3}$. It produces bioactive matters like antibiotics [23]. Also, Inbar et al. [32] referred to produce metabolism byproducts such as antibiotics and extracellular enzymes in compost which has force toward some fungal pathogens.

Streptomyces has important ecological roles in decomposition of organic matters such as plant wastes, manure and organic fertilizers by using keratinase and chitinase as nitrogen and carbon sources [33] and cellulose [34]. Hopkins et al. [35] and Motr [36] used isolated Streptomyces in the decomposing biotechnology because it is capable to use and utilize lignin and cellulosic matters as carbon source with inhibitory activity against pathogens and undesirable fungi. Streptomyces is useful in increasing yield and important physiochemical properties of compost by its byproducts and its biomass [30]. That agrees with 
positive correlation between nitrogen content in compost and in mushroom from side [27], and with results of this experiment form other one.

Growth of bacteria especially Streptomyces essential to grow $A$. bisporus because of its effective on C: $\mathrm{N}$ ratio which lead to induce the primordial formation $[37,38]$. This bacterium play useful role to prevent stay vegetable phase of $A$. bisporus and induce fruiting bodies formation [39]. These results agree with findings of Sanchez and Royse [40] and Straatsma et al. [41], they refereed for producing chosen compost for A. bispoorus cultivation by using Scytalidium thermophilum and some thermophilic fungi to decomposed lignocellulosic wastes.

\section{CONCLUSIONS}

The treatment of compost using Streptomyces inoculum leads to increase the total yield of A. bisporus X25 during 21 days to $430 \mathrm{~g} / \mathrm{box}$ compared without treatment ( $376.94 \mathrm{~g} / \mathrm{box})$. The treated reed straw compost showed higher yield $496.33 \mathrm{~g} / \mathrm{box}$. Using bacterial inoculum given biological efficiency $26.3 \%$ compared without treatment $23.8 \%$. The best biological efficiency was $29.3 \%$ with the treated reed straw compost, while the lower biological efficiency was $20.8 \%$ for the treated mixture compost. Quality and size of fruiting bodies were varied from compost to another depended on diameter of cap (pileus), length of stipe. The bigger diameter had been showed on fruits of reed straw compost $(55.83$ $\mathrm{mm}$ ) while the smaller diameter was $42.33 \mathrm{~mm}$ on fruits of control.

\section{ACKNOWLEDGEMENTS}

Authors thank Mr. Fahad Al- Khirbit and the Hameediyah Mushroom Farm (HMF), Kilo 18, Ramadi, Iraq, to supply spawn for this trial.

\section{References}

1. S.-T. Chang, P.G. Miles, Mushrooms Cultivation, Nutritional Value, Medicinal Effect and Enviromental Impact, 2nd Ed, CRC Press LLC. USA, pp. 451, (2004).

2. J.M. Stephens, Mushroom - Agaricus bisporus (Lge.) Sing. Document is HS628, Institute of Food and Agricultural Sciences, University of Florida, Gainesville FL 32611, (2003).
3. G. Zervakis, A. Philippoussis, Management of agroindustrial waste through the cultivation of edible mushrooms, Proceedings of the fourth European Waste Forum Innovation in Waste Management, Millan, pp. 87-90, (2000).

4. E. Baysal, O.N. Yigitbasi, M. Colak, H. Toker, H. Simsek, F. Yilmaz, Cultivation of Agaricus bisporus on Some Compost Formulas and Locally Available Casing Materials. Part 1: Wheat Straw Based Compost Formulas and Locally Available Casing Materials, Afr. J. Biotechnol., 6 (2007) 2225-2230.

5. O. Schmidt, Wood and Tree Fungi, Biology, Damage, Protection and Use, Springer, Germany, pp. 334, (2006).

6. H. Simsek, E. Baysal, M. Colak, H. Toker, F. Yilmaz, Yield Response of Mushroom (Agaricus bisporus) on Wheat Straw and Waste Tea Leaves Based Composts Using Supplements of Some Locally Available Peats and their Mixture with Some Secondary Casing Materials, Afr. J. Biotechnol., 7 (2008) 88-94.

7. Y.N. Sassine, A.M.R. Abdel-Mawgoud, Y. Ghora, M. Bohme, Effect of Different Mixtures with Waste Paper as Casing Soil on the Growth and Production of Mushroom (Agaricus bisporus), Australian Journal of Basic and Applied Sciences, 1 (2007) 96-104.

8. M.N. Alheeti, I.A. Al-Assaffii, M.M. Muslat, Evalution the efficiency of reed plant (Phragmites australis) wastes and aqueous extract of Liquorices (Glycyrrhiza glabra) on the production of Agaricus bisporus, Journal of University of Anbar for Pure Science, 4 (2010) 13-21.

9. M.M. Muslat, I.A. Al-Assaffii, M.N. Alheeti, A Study of Some Physical and Chemical Characteristics for Compost of Heterogeneous of Cellulose during the Fermentation Period for Mushroom Cultivation of Agaricus bisporus, Al-Anbar Journal of Agricultural Sciences, 9 (2011) 197-206.

10. M.M. Muslat, I.A.A. Al-Assaffii, M.N.O. Alheeti, Use Efficiency of Reed Residues Phragmites australis with Amendment by Streptomyces $\mathrm{O} 3$ to Prepared Compost for Agaricus bisporus Production and Influence of Spraying Glycyrrhiza sp. extracts, Research Journal of Aleppo University. Agricultural Science Series, 93 (2011) 149-168.

11. M.M. Muslat, I.A.A. Al-Assaffii, M.N. Owaid, Agaricus bisporus product development by using local substrate with bio-amendment, International Journal for Environment and Global Climate, 2 (2014) 176-188.

12. D.M. Beyer. Basic Procedures for Agaricus Mushroom Growing, Penn State College of Agricultural Sciences Research, Extension, and Resident Education Programs, Pennsylvania, Chester, pp. 16, (2003).

13. D.H. Tamberkar, T.P. Sonar, M.V. Khodke, B.S. Khante, The novel antibacterial from two edible mushrooms: Agaricus bisporus and Pleurotus sajor caju, International Journal of Pharmacology, 2 (2006) 584-587.

14. J.S. Roberts, A. Teichert, T.H. Mc Hugh, Vitamin D2 Formation from Post-Harvest UV-B Treatment of Mushrooms (Agaricus bisporus) and Retention during Storage, J Agaric Food Chem, 56 (2008) 4541-4544.

15. G.M. Halpern, Healing Mushrooms, Squareone Publishers, USA, (2006) pp. 182. 
16. M.N. Owaid, Mineral elements content in two sources of Agaricus bisporus in Iraqi market, Journal of Advanced \& Applied Sciences, 3 (2015) 46-50.

17. USDA, Mesopotamian Minute, Current News on Agriculture \& USDA in Iraq - Office of Agricultural Affairs, U.S. Embassy, Baghdad, 24th April, pp.1, (2011).

18. R. Locci. Streptomyces and related genera, In: Williams ST, Sharpe ME, Holt JG eds., Bergy's Manual of Systematic Bacteriology, Williams and Wilkins Co., Baltimare, 4 (1989) 2451-2508

19. P. David, C.M. Sheare, Isolation of Actinomycetes for biotechnological application, Northern Regional Research Center, Agricultural Research Service, US, Agriculture Dep., Peoria, Illinois, 61604, pp. 1-29, (1988).

20. O. Adekunle, A study of the properties of ultraviolet radiation induced mutants of Streptomyces cattleya, using numerical taxonomy techniques for the selection of mutants with improved antibiotic yields, Ph.D. thesis, Surrey Uni., UK, (1985).

21. M. Alexander, Introduction to soil microbiology, 2nd ed., Cornell University, New York, London, pp. 36-51, (1976).

22. J.R. C.Fordyce, Relative numbers of certain microbial groups present in compost used for mushroom (Agaricus bisporus) propagation, Applied Microbiology, 20 (1970) 196-199.

23. T.Y. Motr, Test the inhibition activity of two local Streptomyces isolates by used sawdust as a carbone source, Al-Anbar University Journal for Pure Sciences, 2 (2009) 81-69.

24. M.N. Owaid, Biotechnology for local compost preparation used to produce mushroom Agaricus bisporus, M.Sc. thesis, Dep. Biology, College of Science, University of Anbar, Iraq, 129 pp., (2009).

25. D.J. Royse, Spawning to Casing in Commerical Mushroom Production, The Pennsylvania State University, University Park, PA 16802, (2008).

26. A.-S. Edit, M. Dinka, L. Nemedi, G. Horvath, Decompostion of Phragmites australis rhizome in a Shallow Lake, Aquatic Botany, 85 (2006) 309-316.

27. H,B. Aswad, Effect of microbial biotechnological and media mixtures on production of Oyster Mushroom (Pleurotus ostreatus), M.Sc. thesis, College of Agriculture, University of Anbar, Iraq, pp. 78, (2005).

28. T.R. Fermor, W.D. Grant, Degradation of Fungal and Actinomycete Mycelia by Agaricus bisporus, J Gen Microbiol, 131 (1985) 1729-1734.

29. E. Inbar, S.J. Green, Y. Hadar, D. Minz, Competing factors of compost concentration and proximity to root affect the distribution of Streptomyces, Microbiology Ecology, 50 (2005) 73-81.
30. A.G. Chigaleichik, A.N Shkidchenko, D.A. Pirieva, Chilinolytic activity of Actinomyces kurssanovii under conditions of periodic and continuous culturing, Prikl Biokhim Mikrobiol, 14 (1978) 412-416.

31. M. Ishaque, D. Kluepfel, Cellulase complex of a mesophilic Streptomyces flavogriseus strain, Can J Microbiol, 26 (1980) 183-189.

32. D. Wood, Primordium Formation in Axenic Cultures of A. bisporus (Lang). Sing, J Gen Microbiol, 95 (1976) 313-323.

33. S. Chen, C. Qiu, T. Huang, W. Zhou, Y. Qi, Y. Gao, J. Shen, L. Qiu, Effect of 1-aminocyclopropane-1carboxylic acid deaminase producing bacteria on the hyphal growth and primordium initiation of Agaricus bisporus, Fungal Ecology, 6 (2013) 110-118.

34. G. Straatsma, J.P.G. Gerrits, M.P.A.M. Augustijn, H.J.M. Camp, G.D. Vogels, L.J.L.D. Griendsven, Population Dynamics of Scytalidium thermophilum in Mushroom Compost and Stimulatory Effects on Growth Rate and Yield of Agaricus bisporus, J. Gen. Microbiol., 135 (1989) 751-759.

35. J.E. Sanchez, D.J. Royse, Scytalidium thermophilum Colonized Grain, Corn Cobs and Chopped Wheat Straw Substrates for the Production of A. bisporus, Bioresource Technology, 100 (2008) 1670-1674.

36. F. Zarenejad, B. Yakhchali, I. Rasooli, Evaluation of indigenous potent mushroom growth promoting bacteria (MGPB) on Agaricus bisporus production, World J. Microbiol. Biotechnol., 28 (2012) 99-104.

37. M. Tuomela, M. Vikman, A. Hatakka, M. Itavaara, Biodegradation of Lignin in a Compost Enviroment: a Review, Bioresource Technology, 72 (2000) 169-183.

38. D.K. Mercer, M. Iqbal, P.G.G. Miller, A.J. McCarthy, Screening Actinomycetes for Extracellular Peroxidase Activity, Applied and Enviromental Microbiology, 62 (1996) 2186-2190.

39. D. Wood, Primordium Formation in Axenic Cultures of A. bisporus (Lang). Sing, J. Gen. Microbiol., 95 (1976) 313-323.

40. J.E. Sanchez, D.J. Royse, Scytalidium thermophilum Colonized Grain, Corn Cobs and Chopped Wheat Straw Substrates for the Production of A. bisporus, Bioresource Technology, 100(4) (2008) 1670-1674.

41. G. Straatsma, J.P.G. Gerrits, M.P.A.M. Augustijn, H.J.M. Camp, G.D. Vogels, L.J.L.D. Griendsven, Population Dynamics of Scytalidium thermophilum in Mushroom Compost and Stimulatory Effects on Growth Rate and Yield of Agaricus bisporus, J. Gen. Microbiol., 135 (1989) 751-759. 